\title{
Evaluation on Container Products in East Nilam Terminal, Tanjung Perak Port
}

\author{
Haris Zonakis Timur \\ Directorate General of Sea Transport, Ministry of Transportation, Central Jakarta, INDONESIA \\ haristimor84@gmail.com
}

\begin{abstract}
Development of a container terminal is needed due to a change in the region, cargo handling, ship technology, and changes in quantity demand. Performance indicators of container terminal needed to assess the streamlined of container terminals' operational process in serving the transportation of goods and development activities in the future. The analysis of performance indicator in container terminal will have an impact on improving the current services and future. Therefore, there should be a study to measure the performance indicator in ports or container terminals, especially in the Multipurpose Terminal East Nilam (TMNT) as an object of the research. The performance of container terminal as a system with many variables influence can be analyzed with the forecasting method and related theory of applicable equations as well as the application of the model scenarios. Forecasting methods are used to determine TMNT for short-term conditions (2020), medium term (2030), and longterm (2040). The results of the data analysis for the research activities of the secondary data obtained from Indonesian Port Company III branch of Tanjung Perak in 2013, obtained the performance TMNT including BOR (performance dock) 51\% and YOR (yard performance) $31 \%$. The analysis shows that in 2040, it needs a dock length of about TMNT 1,254 meters by nine moorings from existing conditions along the 320 meters with two moorings. The length of East Nilam pier that is not in the revitalization is 540 meters. The development of infrastructure is only possible along the pier of 860 meters with six moorings. While the CY (Container Yard) area needs about 5 acres from existing condition, which is around 3.8 acres. BOR value and YOR projection reach up to $161 \%$ and $145 \%$. This evidence means that the TMNT with existing conditions cannot be used again in 2040. The application of CY scenario model by adding 860 meters of dock length with six moorings, will add capacity of the dock up to 600,000 TEUs, and elimination of not operating time is capable of lowering the value of the BOR become $41 \%$ and YOR become $69 \%$.
\end{abstract}

Keywords: performance of container terminal, performance indicator, BOR, YOR, forecasting method

\section{INTRODUCTION}

Port has an important role in accelerating the development of the region. Therefore, the existence of basic and supporting of port facilities should be continuously improved to support its operational activities (Jinca, 2011; Suranto, 2004; Kramadibrata, 2002).

Due to the enhancement of the port facility, Indonesian Port Company III (2008) branch of Tanjung Perak Surabaya developed the Multi-Purpose Terminal of East Nilam (Terminal Multipurpose Nilam Timur-TMNT). On February 2009, after a year construction, the pier of 320 meters was already set for operation. This terminal will increase the loading and unload speed in Tanjung Perak Port, as previously the loading and unloading still relied on ship crane, by using this Container Crane the speed will increase for it is able to handle domestic container as much as 20 boxes/crane/hour. This then could decrease the ship queue density in Tanjung Perak Port and also increase trade fluency in East Java, especially those with water transportation. The conducted revitalization was by carrying out enhancement stages on the pier, modernizing warehouse into container yard (CY), and providing adequate loading and unloading equipment specific for the container.

The purpose and objective of this research was to discover the projection of container flow in the Multipurpose Terminal of East Nilam, in order to find the requirement for enhancement and development of the dock capacity, the need for the container yard area, and the need for loading and unloading facility equipment on year 2020, 2030, and 2040, to find the container performance in loading and unloading speed, waiting time, Berth Occupancy Ratio (BOR), and Yard Occupancy Ratio (YOR); and to evaluate the performance and readiness of the loading and unloading equipment in the terminal, so the Berth Working Time (BWT) is compatible as previously set; also, to decide required attempts to keep the Multipurpose Terminal of East Nilam stays optimum. 


\section{INFRASTRUCTURE CAPACITY AND PORT PERFORMANCE}

One of the port basic facilities is a terminal which should have a good plan to allow the ship docked and conducted activities safely, quickly, and smoothly (Triatmojo, 2003, 2010; Yuwono, 2009).

\subsection{Dock Capacity}

Dock capacity is the dock ability to receive the container loading and unloading flow. It is formulated as follows:

$$
K D=L \times B T P \times f
$$

whereas $K D$ is installed capacity (TEUs, tons, $\mathrm{m}^{3}$, box), $L$ is length of the berth (m), BTP is berth throughput (TEUs, tons, $\mathrm{m}^{3}$, box/m/year), and $f$ is conversion factor (to convert unit box to TEUs, i.e. 1 box $=1.7$ TEUs).

\subsection{Pier Length}

There are two methods to calculate the need for pier length, which is by container ship arrival flow, and by container ship flow. The first method is by using IMO (International Maritime Organization) formula, as follows,

$$
L=n \times L_{1}+10 \% L_{o a}
$$

whereas $L_{l}$ is the length of the berth to the ship, $L_{o a}$ is vessel length (m), and $L$ is berth length which consists of $n$ berth estimated using the following equation.

The second method is by using equation as follows,

$$
L=\frac{X}{B T P}
$$

whereas $X$ is a number of containers (TEUs/year), $B T P$ is berth throughput $\left(\mathrm{m}^{3}\right.$, ton, box or TEUs/m/year).

\subsection{Container Yard Need}

The container yard need could be estimated by using Equation (4):

$$
A=\frac{T \times D T \times S_{f}}{365 S_{t h}(1-B S)}
$$

whereas $A$ is warehouse/yard area $\left(\mathrm{m}^{2}\right), \quad T$ is throughput per year (the charged container that passes every year, tons), $D T$ is dwelling time (transit time, day), $S f$ is Stowage factor (the average volume of each commodity, $\mathrm{m}^{3} / \mathrm{ton}$ ), Sth is Stacking height (height of stack charged container, $\mathrm{m}$ ), $B S$ is Broken Stowage of cargo (missing volume, \%) and 365 represents the number of days in a year.

\subsection{Equipment Capacity}

The equipment capacities that will be analyzed in this subject are Container Crane (CC), Transtainer/RTG (Rubber Truck Gantry Crane), Head Truck and Chassis. Variables that took part in determining the equipment capacity are as follows,
a) Equipment amount, $n$ (unit)
b) Berth Occupancy Ratio, BOR (\%)
c) Service speed, $B$ (box/hour/equipment)
d) Working time in 1 year, $H$ (days)
e) Effective hour, $S t$ (hour)
f) Conversion factor of box to TEUs $=1.5$

From above variable, per each equipment Throughput Capacity (Tc) could be determined by using this equation:

$$
T c=B \times S t \times H \times B O R \times 1.3
$$

\subsection{Container Terminal Performance Measurement}

The port performance was showed by Berth Occupancy Ratio $(B O R)$ or the dock utilization level, which is the comparison between amounts of time the dock is utilized and the amount of time available for one period, stated in percentage. The port performance indicator was applied to measure how far the port facility and supporting facility are utilized intensively. The BOR could be calculated with equation as follows,

$$
B O R=\left(\frac{V s \times S t}{H \times n}\right) 100 \%
$$

whereas $B O R$ is Berth Occupancy Ratio (\%), $V s$ is a number of vessels serviced (units/year), $S t$ is Service time (hours/day), $n$ is a number of moorings and $H$ is the number of working days in a year.

The rating of utilization of a container terminal could be shown by indicators such as the dock's berth throughput, Berth Occupancy Ratio (BOR), and the Container Yard Occupancy Ratio. Berth Throughput $(B T P)$ is the dock ability to put through the amount of container that is loading and unloading in the mooring. BTP could be calculated with equation as follows,

$$
B T P=\frac{H \times B O R \times J \times G \times P}{L_{1}}
$$


whereas $J$ is the hours of work per day, $G$ is number gang at a time, $P$ is unloading productivity $\left(\mathrm{m}^{3}\right.$, ton, box, or TEUs/hour).

The analysis on container yard performance (Container Yard Occupancy Ratio-CYOR) and Container Yard Berth Throughput (CYTP) could be calculated with equation as follows,

$$
\begin{aligned}
& \text { CYOR }=\left(\frac{X}{C Y \times 365}\right) 100 \% \\
& C Y T P=\frac{X}{C Y}
\end{aligned}
$$

To calculate the utilization level of the port production equipment, such as container crane, RTG, and head truck, as follows equation was used:

$$
U=\left(\frac{X}{N \times Y \times H \times S t}\right) 100 \%
$$

$U$ is container crane utility (\%): estimation of the total container that the port could carry per year, $N$ : crane amount, $Y$ : total containers the crane carries per hour

\subsection{Forecasting Method}

The forecasting method is the way to predict what will happen in the future, systematically and pragmatically, based on the relevant data in the past as can be seen from the flowchart of Figure 1.

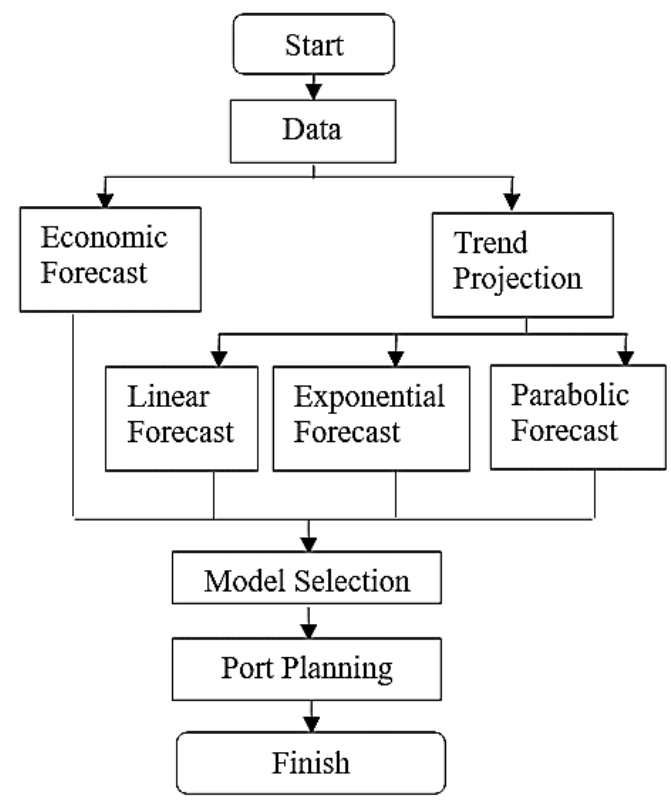

Figure 1.Forecasting scheme.
The purpose of the forecasting method is to help the approach analysis on behavior or data pattern in the past, in order to give the way of reasoning, processing, systematic and pragmatic solution, also to deliver the level of assurance on the forecasting result accuracy. There are four forecasting methods which are the linear, exponential, parabolic, and econometric forecast. From these methods, the one with the lowest deviation standard from existing data will be chosen. (Makridakis, 1988; Arsyad, 1994).

\section{RESEARCH METHOD}

In this research, points that were conducted are the secondary data collection (ship flow, container flow data, loading and unloading equipment data), and regional gross domestic income (Pendapatan Domestik Regional Bruto-PDRB) on 2009-2003, then it all be analyzed with chosen forecasting method, with the result of container flow prediction. Afterward, the calculation was conducted for analyzing the dock facility need, the container loading and unloading equipment for 2020, 2030, and 2040.

\section{RESEARCH RESULT AND DISCUSSION}

\subsection{Research Object General Description}

Table 11 is shown the data obtained from 2009 to 2013. The export/import flow of container is basically influenced by the economic factor of a region. Logically as the regional gross domestic income (PDRB) increasing, a region will be influenced positively by its export value/volume growth (Timor, 2014). Data on the performance of the service and the facility of TMNT at 2014 is shown in Table 2.

Table 1. Existing the data year 2009 to 2013 (Indonesian Port Company III, 2013)

\begin{tabular}{lllll}
\hline Year & $\begin{array}{l}\text { Container } \\
\text { flow } \\
\text { (TEUs) }\end{array}$ & $\begin{array}{l}\text { Ship } \\
\text { flow } \\
\text { (Unit) }\end{array}$ & $\begin{array}{l}\text { East Java PDRB } \\
\text { (Million Rupiah) }\end{array}$ & $\begin{array}{l}\text { Economy } \\
\text { development } \\
(\%)\end{array}$ \\
\hline 2009 & 86,391 & 367 & $684,116,348.35$ & 5.01 \\
2010 & 146,179 & 561 & $778,116,348.35$ & 6.68 \\
2011 & 227,987 & 589 & $884,519,235.37$ & 7.22 \\
2012 & 254,207 & 611 & $1,001,280,116.50$ & 7.27 \\
2013 & 264,754 & 638 & $1,136,368,360.33$ & 6.55 \\
\hline
\end{tabular}


Table 2. Performance of the service and facility of TMNT

\begin{tabular}{|c|c|c|}
\hline No & Parameter & Quantity \\
\hline \multirow[t]{2}{*}{1} & Dock & \\
\hline & Length (m) & 320 \\
\hline \multirow[t]{3}{*}{2} & Container Yard & \\
\hline & Area & 3.8 \\
\hline & Capacity & 285,000 \\
\hline \multirow[t]{4}{*}{3} & Productivity & \\
\hline & Working day & 365 \\
\hline & Working time & 24 \\
\hline & Total working group & 2 group \\
\hline \multirow[t]{6}{*}{4} & Container Crane (CC) & \\
\hline & Total (units) & 3 \\
\hline & Service speed (box/hour/CC) & 22 \\
\hline & Working time (hour/year) & 7300 \\
\hline & Utility $(\%)$ & 65 \\
\hline & Availability $(\%)$ & 92.97 \\
\hline \multirow[t]{6}{*}{5} & Rubber Tired Gantry (RTG) & \\
\hline & Total (units) & $5 \mathrm{t}$ \\
\hline & Service speed (box/hour/CC) & 17 \\
\hline & Working time (hour/year) & 7300 \\
\hline & Utility $(\%)$ & 50.37 \\
\hline & Availability (\%) & 98.60 \\
\hline \multirow[t]{6}{*}{6} & Head Truck and Chassis (HT) & \\
\hline & Total (units) & 12 \\
\hline & Service speed (box/hour/CC) & 10 \\
\hline & Working time (hour/year) & 7300 \\
\hline & Utility $(\%)$ & 37 \\
\hline & Availability $(\%)$ & 99 \\
\hline \multirow[t]{6}{*}{7} & Container ship performance & \\
\hline & Berthing Time (hour) & 24.71 \\
\hline & Idle Time (hour) & 1.58 \\
\hline & Effective Time (hour) & 16.34 \\
\hline & Not Operating Time (hour) & 6.01 \\
\hline & ET to BT (hour) & 66.15 \\
\hline \multirow[t]{3}{*}{8} & $\begin{array}{l}\text { Container Yard (CY) and container dock } \\
\text { utilization }\end{array}$ & \\
\hline & Yard Occupancy Ratio (\%) & 31 \\
\hline & Berth Occupancy Ratio (\%) & 51 \\
\hline
\end{tabular}

4.2 Projection Ship Arrival Flow and Container Flow

The projection was conducted by using the regression analysis, which in this case by using the Microsoft Excel software. On Table 3 is the regression result for ship flow that has equation as follows,

Table 3. Ship flow regression

\begin{tabular}{|c|c|c|}
\hline \multicolumn{3}{|c|}{ Regression Statistics } \\
\hline Multiple R & & 0.8677 \\
\hline R Square & & 0.753 \\
\hline Adjusted R Square & & 0.671 \\
\hline Standard Error & & 61.910 \\
\hline \multirow[t]{2}{*}{ Observations } & & 5 \\
\hline & Coefficients & Standard error \\
\hline Intercept & 118498 & 39370.439 \\
\hline Year & 59.2 & 19.578 \\
\hline
\end{tabular}

The regression analysis showed that the equation of ship flow year $x$ is $Y=-118498+59.2 x$ with $R^{2}=0.7529$. Based on the equation, the projection of the ship arrival flow until 2014 could be known. As can be seen from the graph of Figure 2.

On Figure 3, the prediction on container flow based on 2009 to 2013 for next 10 years was using 4 analysis methods, which is the forecast linear, forecast exponential, forecast parabolic, and forecast econometric.

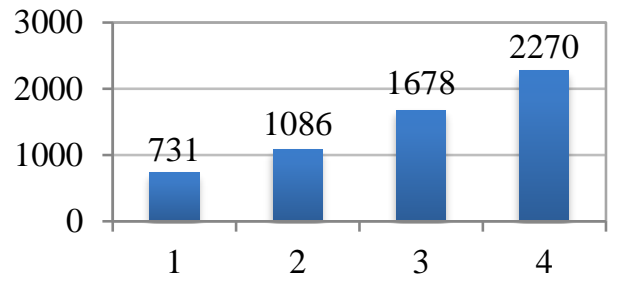

Figure 2. Projection ship.

From these methods, the one with lower deviation standard from existing data will be chosen. Table 4 shows the projection result from the four methods being used. Furthermore, the forecasting result for 2014 to 2040 based on forecast econometric method with equation $y=-164764.1954+0.000402136 x$ and $R^{2}=0.8743$ showed that the container flow could reach around 604,032 TEUs in 2020.

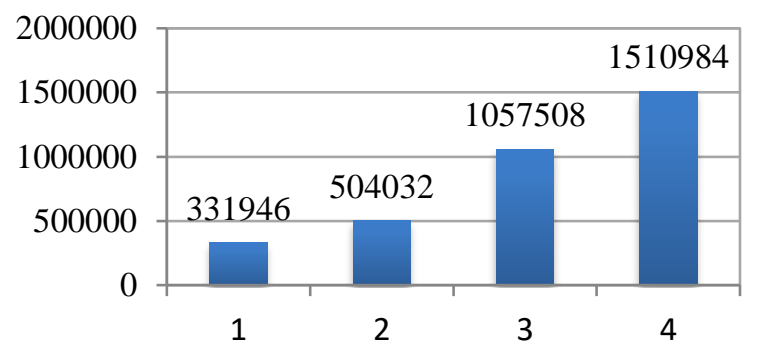

Figure 3. Container projection.

\subsection{Analysis on Terminal Facility Need}

When calculating the BOR value, the Service Time $(S t)$ has to be previously calculated, with the assumption that Not Operating Time (NOT) is $20 \%$ of loading and unloading effective time with 2 moorings, effective time is 365 days, and the total group is 2 . The BOR projection value with Equation (3) can be seen in Table 5. The projection result on the need for mooring, based on theory and equation, could be seen in Table 6. 
Table 4. Comparison on the 4-forecasting method deviation

\begin{tabular}{llllllllll}
\hline Year & \multicolumn{2}{l}{ Container flow } & \multicolumn{2}{c}{ Linear deviation } & \multicolumn{2}{c}{ Exponential deviation } & \multicolumn{2}{c}{ Parabolic deviation } & \multicolumn{2}{c}{ Econometric deviation } \\
& (teus) & Value & $\%$ & Value & $\%$ & Value & $\%$ & Value & $\%$ \\
\hline 2009 & 86,391 & 54,561 & 63.16 & 22,933 & 26.55 & 57,750 & 66.85 & 18,817 & 21.78 \\
2010 & 146,179 & 62,075 & 42.47 & 56,488 & 38.64 & 61,437 & 42.03 & 4,377 & 2.99 \\
2011 & 227,987 & 91,609 & 40.18 & 101,217 & 44.40 & 87,143 & 38.22 & 32,083 & 14.07 \\
2012 & 254,207 & 65,555 & 25.79 & 75,031 & 29.52 & 57,262 & 22.53 & 12,956 & 5.10 \\
2013 & 264,754 & 23,828 & 9.00 & 11,506 & 4.35 & 11,708 & 4.42 & 21,845 & 8.25 \\
\hline Deviation & Standard & 36.12 & & 28.69 & & 34.81 & & 10.44 \\
\hline
\end{tabular}

Table 5. BOR projection value

\begin{tabular}{llll}
\hline Year & $\begin{array}{l}\text { Container flow } \\
\text { (TEUs) }\end{array}$ & $\begin{array}{l}\text { Service } \\
\text { time } \\
(\text { Hour })\end{array}$ & $\begin{array}{l}\text { BOR } \\
\text { projection } \\
(\%)\end{array}$ \\
\hline 2014 & 331,946 & 12.39 & 52 \\
2020 & 604,032 & 12.39 & 77 \\
2030 & $1,057,508$ & 12.39 & 119 \\
2040 & $1,510,984$ & 12.39 & 161 \\
\hline
\end{tabular}

Table 6. Comparison on need for mooring

\begin{tabular}{llllll}
\hline \multirow{2}{*}{ Year } & \multirow{2}{*}{$\begin{array}{l}\text { Ship } \\
\text { flow }\end{array}$} & \multirow{2}{*}{$\begin{array}{l}\text { Service } \\
\text { time }\end{array}$} & \multicolumn{3}{c}{ Mooring } \\
\cline { 4 - 6 } & (Unit) & (Hour) & Exist & UNC & Directorate \\
ing & TAD & general \\
\hline 2014 & 731 & 12.39 & 2 & 2 & 1 \\
2020 & 790 & 12.39 & 2 & 4 & 3 \\
2030 & 1.678 & 12.39 & 2 & 7 & 5 \\
2040 & 2.27 & 12.39 & 2 & 9 & 7 \\
\hline
\end{tabular}

The need for pier length could be calculated based on either container flow or ship arrival flow. Based on the container flow, by applying the mean length of the ship that arrives, the need for pier length is 120 meters, as shown in Table 7.

Table 7. Pier length according to container flow

\begin{tabular}{lllll}
\hline Year & $\begin{array}{l}\text { Container } \\
\text { Flow } \\
\text { (TEUs) }\end{array}$ & $\begin{array}{l}\text { Pier } \\
\text { Length 1 } \\
\text { Ship/L1 } \\
(\mathrm{m})\end{array}$ & $\begin{array}{l}\text { BTP } \\
\text { Projection } \\
\text { (TEUs/m/ } \\
\text { year) }\end{array}$ & $\begin{array}{l}\text { Pier } \\
(\mathrm{m})\end{array}$ \\
\hline 2014 & 331,946 & 132 & 1,518 & 219 \\
2020 & 604,032 & 132 & 2,248 & 398 \\
2030 & $1,057,508$ & 132 & 3,464 & 696 \\
2040 & $1,510,984$ & 132 & 4,687 & 995 \\
\hline
\end{tabular}

Based on ship arrival flow, the pier length that resulted is as seen in Table 8 .
Table 8. Pier length according to ship flow

\begin{tabular}{lllll}
\hline Year & $\begin{array}{l}\text { Ship } \\
\text { Flow } \\
\text { (Unit) }\end{array}$ & $\begin{array}{l}\text { Ship Mean } \\
\text { Length(m) }\end{array}$ & $\begin{array}{l}\text { Total } \\
\text { Mooring } \\
\text { (UNCTAD) }\end{array}$ & $\begin{array}{l}\text { Pier } \\
(\mathrm{m})\end{array}$ \\
\hline 2014 & 731 & 120 & 2 & 285 \\
2020 & 1,086 & 120 & 4 & 508 \\
2030 & 1,678 & 120 & 7 & 881 \\
2040 & 2,270 & 120 & 9 & 1254 \\
\hline
\end{tabular}

The dock capacity based on the projection result from the calculation is based on Table 9 .

The requirement of container yard based on Equation (5) is shown in Table 10.

Table 9. Dock capacity

\begin{tabular}{|c|c|c|c|c|}
\hline Year & $\begin{array}{l}\text { Pier } \\
\text { Length } \\
(\mathrm{m})\end{array}$ & $\begin{array}{l}B T P \\
\text { projection } \\
\text { (TEUs/m/ } \\
\text { Year) }\end{array}$ & $\begin{array}{l}B T P \\
\text { projection } \\
\text { (TEUs/ } \\
\text { Year) }\end{array}$ & $\begin{array}{l}\text { Dock } \\
\text { capacity } \\
\text { (TEUs) }\end{array}$ \\
\hline 2014 & 285 & 1,518 & 485,888 & 492,49 \\
\hline 2020 & 508 & 2,248 & 719,488 & $1,143,232$ \\
\hline 2030 & 881 & 3,464 & $1,108,634$ & $3,052,848$ \\
\hline 2040 & 1254 & 4,687 & $1,499,762$ & $5,876,743$ \\
\hline
\end{tabular}

Table 10. Requirement of container yard

\begin{tabular}{llllll}
\hline Year & $D T$ (days) & Sth & $B s$ & $S f$ & $A($ ha) \\
\hline 2014 & 5 & 3 & 0.4 & 29 & 1.10 \\
2020 & 5 & 3 & 0.4 & 29 & 2.00 \\
2030 & 5 & 3 & 0.4 & 29 & 3.50 \\
2040 & 5 & 3 & 0.4 & 29 & 5.00 \\
\hline
\end{tabular}

In order to $C Y O R$ value to be decreased and reach a good value, the area of container yard on 2024 needs to be increased. The YOR value and $C Y T P$ value could be calculated by using Equation (9) and Equation (10). Table 11 showed the performance from the container yard. 
Table 11. $C Y T P$ value and $Y O R$ value

\begin{tabular}{llll}
\hline Year & $\begin{array}{l}\text { Container } \\
\text { Flow(TEUs) }\end{array}$ & $\begin{array}{l}\text { CYTP } \\
(\text { TEUs/m/Year) }\end{array}$ & $\begin{array}{l}\text { CYOR } \\
(\%)\end{array}$ \\
\hline 2014 & 331,946 & 909 & 32 \\
2020 & 604,032 & 1,655 & 58 \\
2030 & $1,057,508$ & 2,897 & 102 \\
2040 & $1,510,984$ & 4,140 & 145 \\
\hline
\end{tabular}

\subsection{The Need for Equipment}

To find out the need for equipment, it is necessary to calculate the equipment, Throughput Capacity $(T c)$, by using the Equation (6). As follows are several variables that used:

a) Working time $(D) \quad: 365$ days

b) Working hour $(H): 20$ hours

c) Conversion Factor : 1.5

d) CC speed $(B) \quad: 22$ box/group/cc

e) RTG speed $: 17 \mathrm{box} /$ group/RTG

f) HT speed $\quad: 10 \mathrm{box} /$ group/HT

g) BOR and Directorate General (70\%): UNCTAD standard $(50 \%)$

The need for Container Crane (CC), Rubber Tired Gantry Crane (RTG), Head Truck and Chassis (HT) is shown from Table 12 thru Table 14, consecutively.

Table 12. The need for Container Crane (CC)

\begin{tabular}{lllll}
\hline \multirow{2}{*}{ Year } & \multicolumn{2}{c}{ UNCTAD } & \multicolumn{2}{c}{ Directorate General } \\
\cline { 2 - 5 } & $T c$ (TEUs) & CC (unit) & $T c$ (TEUs) & CC(unit) \\
\hline 2020 & 120,450 & 5 & 168,630 & 4 \\
2030 & 120,450 & 9 & 168,630 & 6 \\
2040 & 120,450 & 13 & 168,630 & 9 \\
\hline
\end{tabular}

Table 13. The need for Rubber Tired Gantry Crane (RTG)

\begin{tabular}{lllll}
\hline \multirow{2}{*}{ Year } & \multicolumn{2}{c}{ UNCTAD } & \multicolumn{2}{c}{ Directorate General } \\
\cline { 2 - 5 } & Tc(TEUs) & RTG(unit) & Tc (TEUs) & RTG (unit) \\
\hline 2014 & 93,075 & 4 & 130,305 & 3 \\
2020 & 93,075 & 6 & 130,305 & 5 \\
2030 & 93,075 & 11 & 130,305 & 8 \\
2040 & 93,075 & 16 & 130,305 & 12 \\
\hline
\end{tabular}

Table 14. The need for Head Truck and Chassis (HT)

\begin{tabular}{lllll}
\hline \multirow{2}{*}{ Year } & \multicolumn{2}{c}{ UNCTAD } & \multicolumn{2}{c}{ Directorate General } \\
\cline { 2 - 5 } & Tc(TEUs) & HT(unit) & $T c$ (TEUs) & HT(unit) \\
\hline 2014 & 54,750 & 6 & 76,650 & 4 \\
2020 & 54,750 & 11 & 76,650 & 8 \\
2030 & 54,750 & 19 & 76,650 & 14 \\
2040 & 54,750 & 28 & 76,650 & 20 \\
\hline
\end{tabular}

\subsection{Port Production Equipment Performance}

The utilization of port production equipment is shown in Table 15. To calculate the utilization level of the port production equipment (Container Crane, RTG, and Head Truck), Equation (13) could be used, with several assumptions as follows,

a) The total amount of container that carried by container crane, RTG, and head truck, consecutively is 22 boxes/CC/hour, 17 boxes/RTG/hour, and 10 boxes/HT/hour

b) Working hour per days $(S t)$ is 20 hours

c) Working days available per year $(H) 365$ days

Table 15. Projection of production equipment

\begin{tabular}{llll}
\hline Year & $\begin{array}{l}\text { Utilization } \\
\text { CC }(\%)\end{array}$ & $\begin{array}{l}\text { Utilization } \\
\text { RTG }(\%)\end{array}$ & $\begin{array}{l}\text { Utilization HT } \\
(\%)\end{array}$ \\
\hline 2014 & 68.9 & 53.5 & 37.89 \\
2020 & 75.22 & 81.12 & 68.95 \\
2030 & 73.16 & 77.47 & 76.24 \\
2040 & 72.37 & 76.1 & 73.92 \\
\hline
\end{tabular}

\subsection{Container Ship Performance}

Table 16 shows the data on the mean performance of the container ship that conducted loading and unloading in TMNT in 2013, compared with the standard recommended by the Directorate General of Sea Transportation (2011). As for the performance of container ship on the current year has not been analyzed, which needed the field data in the current year.

Table 16. Container ship performances on TMNT

\begin{tabular}{llll}
\hline $\begin{array}{l}\text { Container Ship } \\
\text { Performance }\end{array}$ & $\begin{array}{l}\text { Time } \\
\text { (hour) }\end{array}$ & $\begin{array}{l}\text { Standard } \\
\text { (hour) }\end{array}$ & Rating \\
\hline $\begin{array}{l}\text { Turn Round } \\
\text { Time (TRT) }\end{array}$ & 48.37 & - & - \\
$\begin{array}{l}\text { Approach Time } \\
\text { (AT) }\end{array}$ & 4.58 & 4 & $\begin{array}{l}\text { Moderately } \\
\text { Good }\end{array}$ \\
Waiting Time (WT) & 33 & 2 & Not Good \\
Berthing Time (BT) & 24.71 & - & - \\
Idle Time (IT) & 1.58 & - & - \\
Effective Time (ET) & 16.34 & - & - \\
Not Operation & 6.01 & - & - \\
Time (NOT) & & & Moderately \\
ET to BT & $66 \%$ & $70 \%$ & Good \\
\hline
\end{tabular}

\subsection{Comparison on Existing Condition with Projection Year}

In order to find out the Multi-purpose Terminal of East Nilam, it is necessary to have a comparison of existing conditions with upcoming projection year. It is for the anticipation so that the dock performance stays optimal and able to serve the ship flow that 
enters. The existing condition that is meant is the last year condition in TMNT, while the projection year is the short-term, medium-term, and long-term projection year, which is 2020, 2030, and 2040. The comparison on existing condition with projection year is shown in Table 17.

\subsection{Pier Performance Model}

The Scenario A was conducted by adding dock length from 320 meters with 2 moorings, to 860 meters with 6 moorings, and the dock capacity is increased to 600,000 TEUs/year. While the Scenario B was by erasing the Not Operating Time, in order to increase the pier effectiveness; this Not Operating Time will affect the level of pier utilization. The Scenario $C$ was a combination of Scenario A and Scenario B. The Scenario is shown in Table 18.
Table 17. Comparison of existing conditions with projection year

\begin{tabular}{lllll}
\hline \multirow{2}{*}{ Briefing } & Year & & & \\
\cline { 2 - 5 } & Existing & 2020 & 2030 & 2040 \\
\hline Ship(unit) & 638 & 1,086 & 1,678 & 2,270 \\
Container & 264,754 & 604,032 & $1,057,058$ & $1,510,984$ \\
(TEUs) & & 4 & 7 & 9 \\
Mooring & 2 & 508 & 881 & 1,254 \\
Lenght(m) & 320 & & & $5,876,743$ \\
Capacity & 348,634 & $1,143,230$ & $3,052,848$ & \\
(TEUs) & 3.8 & 2.0 & 3.5 & 5.0 \\
CY(a) & 31 & 77 & 119 & 161 \\
BOR(\%) & 51 & 102 & 145 \\
YOR(\%) & 31 & 58 & 9 & 13 \\
CC(unit) & 3 & 5 & 11 & 19 \\
RTG(unit) & 5 & 6 & 19 & 28 \\
HT(unit) & 12 & 11 & 73 & 72 \\
CC(\%) & 65 & 75 & 77 & 76 \\
RTG(\%) & 50 & 81 & 76 & 74 \\
HT(\%) & 37 & 69 & &
\end{tabular}

Table 18. Comparison on performance model

\begin{tabular}{|c|c|c|c|c|c|c|c|c|}
\hline Year & BOR $(\%)$ & BOR (\%) Sc.A & BOR (\%) Sc.B & $B O R(\%)$ Sc.C & YOR $(\%)$ & $\begin{array}{c}\text { YOR (\%) } \\
\text { Sc. A }\end{array}$ & $\begin{array}{c}\text { YOR }(\%) \\
\text { ScK. B }\end{array}$ & $\begin{array}{c}\text { YOR (\%) } \\
\text { Sc. C }\end{array}$ \\
\hline 2014 & 51.67 & - & 39.47 & 39.47 & 31.91 & - & 31.91 & 31.91 \\
\hline 2015 & 55.86 & - & 42.66 & 42.66 & 36.27 & - & 36.27 & 36.27 \\
\hline 2016 & 60.04 & - & 45.85 & 45.85 & 40.63 & - & 40.63 & 40.63 \\
\hline 2017 & 64.23 & - & 49.05 & 49.05 & 44.99 & - & 44.99 & 44.99 \\
\hline 2018 & 68.42 & - & 52.25 & 52.25 & 49.35 & - & 49.35 & 49.35 \\
\hline 2019 & 72.60 & - & 55.44 & 55.44 & 53.71 & - & 53.71 & 53.71 \\
\hline 2020 & 76.79 & 25.60 & 58.64 & 19.55 & 58.07 & 27.58 & 58.07 & 27.58 \\
\hline 2021 & 80.97 & 26.99 & 61.84 & 20.61 & 62.43 & 29.65 & 62.43 & 29.65 \\
\hline 2022 & 85.16 & 28.39 & 65.03 & 21.68 & 66.78 & 31.72 & 66.78 & 31.72 \\
\hline 2023 & 89.35 & 29.78 & 68.23 & 22.74 & 71.14 & 33.79 & 71.14 & 33.79 \\
\hline 2024 & 93.53 & 31.18 & 71.43 & 23.81 & 75.50 & 35.86 & 75.50 & 35.86 \\
\hline 2025 & 97.72 & 32.57 & 74.62 & 24.87 & 79.86 & 37.93 & 79.86 & 37.93 \\
\hline 2026 & 101.90 & 33.97 & 77.82 & 25.94 & 84.22 & 40.01 & 84.22 & 40.01 \\
\hline 2027 & 106.09 & 35.36 & 81.01 & 27.00 & 88.58 & 42.08 & 88.58 & 42.08 \\
\hline 2028 & 110.27 & 36.76 & 84.21 & 28.07 & 92.94 & 44.15 & 92.94 & 44.15 \\
\hline 2029 & 114.46 & 38.15 & 87.41 & 29.14 & 97.30 & 46.22 & 97.30 & 46.22 \\
\hline 2030 & 118.65 & 39.55 & 90.60 & 30.20 & 101.66 & 48.29 & 101.66 & 48.29 \\
\hline 2031 & 122.83 & 40.94 & 93.80 & 31.27 & 106.02 & 50.36 & 106.02 & 50.36 \\
\hline 2032 & 127.02 & 42.34 & 97.00 & 32.33 & 110.38 & 52.43 & 110.38 & 52.43 \\
\hline 2033 & 131.20 & 43.73 & 100.19 & 33.40 & 114.74 & 54.50 & 114.74 & 54.50 \\
\hline 2034 & 135.39 & 45.13 & 103.39 & 34.46 & 119.10 & 56.57 & 119.10 & 56.57 \\
\hline 2035 & 139.58 & 46.53 & 106.59 & 35.53 & 123.46 & 58.64 & 123.46 & 58.64 \\
\hline 2036 & 143.76 & 47.92 & 109.78 & 36.59 & 127.81 & 60.71 & 127.81 & 60.71 \\
\hline 2037 & 147.95 & 49.32 & 112.98 & 37.66 & 132.17 & 62.78 & 132.17 & 62.78 \\
\hline 2038 & 152.13 & 50.71 & 116.18 & 38.73 & 136.53 & 64.85 & 136.53 & 64.85 \\
\hline 2039 & 156.32 & 52.11 & 119.37 & 39.79 & 140.89 & 66.92 & 140.89 & 66.92 \\
\hline 2040 & 160.51 & 53.50 & 122.57 & 40.86 & 145.25 & 68.99 & 145.25 & 68.99 \\
\hline
\end{tabular}




\section{CONCLUSIONS AND SUGGESTIONS}

\subsection{Conclusions}

The following statements are the conclusions that obtained from this research:

a) Based on the calculation with BOR UNCTAD standard, the total amount of mooring needed is 4 in 2020, 7 moorings in 2030, and 9 moorings in 2040. Whereas according to the Directorate General of Sea Transportation standard, the total amount of mooring needed is 3 in 2020; 5 moorings in 2030, and 7 moorings in 2040. In this case, the writer chose to use the higher amount of mooring, which is by the UNCTAD standard. The need for TMNT pier length in 2020 is about 508 meters; about 881 meters in 2030; and about 1,254 meters in 2040.

b) The projection on TMNT Berth Occupancy Ratio $(B O R)$ in 2020 is $77 \%$, around $118 \%$ in 2030 , and in 2040 is around $161 \%$ with service time 12.39 hours. The UNCTAD standard for 2 moorings is maximum 50\%, while the Directorate General of Sea Transportation standard for Nilam pier is maximum $70 \%$. In this case, writer used the UNCTAD standard, which means that the BOR value in TMNT does not meet the recommended standard.

c) The projection on Yard Occupancy Ratio (YOR) value in 2020 is $58 \%$, around $102 \%$ in 2030 , and in 2040 is around $145 \%$. In this case, the writer used the Directorate General of Sea Transportation recommended a standard, which is maximum $70 \%$ for Nilam pier.

d) The need for Containment Yard/CY in 2020 is 2 hectares, around 3.5 hectares in 2030, and in 2040 is around 5 hectares, with 3 container stacks and dwelling time of 5 days. For Yard Throughput (YTP) value is about 2,028 TEUs/m/year.

e) The projection on the need for Container Crane (CC) on year 2020 is 5 units, 9 units in 2030, and in 2040 around 13 units, with the average of utilization level is $74 \%$, and equipment availability of $95 \%$.

f) The need for Rubber Tired Gantry (RTG) in 2020 is 6 units, around 11 units in 2030, and around 16 units in 2040; with the average of utilization level is $71 \%$, and equipment availability of $95 \%$. Whereas the needs for Head Truck (HT) and Chassis in 2020 are 11 units, around 19 units in 2030, and around 28 units in 2040, with the average of utilization level, is $69 \%$, and equipment availability of $95 \%$. g) The average of total time for each ship to Approach Time (AT): 4.58 hours, Waiting Time (WT): 33 hours and Effective Time (ET) to Berthing Time (BT) is 66.15 hours, which is still below the applied standard.

\subsection{Suggestions}

Several suggestions that could be recommended are as follows:

a) Construction of adequate pier by revitalizing the present Nilam pier to 860 meters, in order to cope with the increasing flow of ship arrival.

b) Application of the Scenario C model is expected to increase the operational performance, by decreasing the indicator value of the container and the ship operational service.

c) Adding production equipment according to the needs and increasing the production equipment speed, so that the Berth Working Time (BWT) is fit with what PPSA assigned.

d) Regularly managing the maintenance on the production equipment, in order to make the equipment downtime lower and decreasing the idle time, so the services become more efficient.

e) Enhancement on human resource quality, such as the field operator and administration section, in order to operate the production equipment and work on administration issue maximally.

f) Applying the Information Technology (IT) system, the green port concept, the Work Health and Environment Safety Management System (Sistem Manajemen Keselamatan Kesehatan Kerja dan Lingkungan-SMK3L), also the International Ship Security and Port Facility (ISPS Code), in order to accelerate the operational activity on the field.

\section{REFERENCES}

Arsyad, L., 1994. Peramalan Bisnis [Bussiness

Forcecasting]. Yogyakarta: BPFE.

Directorate General of Sea Transportation, 2011.

Decision Letter No.UM.002/38/18/DJPL-11 on Port

Service and Operational Performance Standard,

Jakarta: Directorate General of Sea Transportation.

Indonesian Port Company III, 2013. Kinerja

Operasional Terminal Multipurpose Nilam Timur

[Operational Performance of Nilam Timur

Multipurpose Terminal]. Surabaya: Indonesian Port

Company III. 
Jinca, M. \& Yamin, 2011. Transportasi Laut Indonesia Analisis Sistem \& Studi Kasus [Case Study and Analytical System of Sea Transportation in Indonesia]. Surabaya: Brilian Internasional.

Kamadibrata, S., 2002. Perencanaan Pelabuhan [Port Design]. Surabaya: ITS.

Makridakis, S., 1988. Metode dan Aplikasi Peramalan [Method and Application of Forecsting]. Yogyakarta: Erlangga.

Suranto, 2004. Manajemen Operasional Angkutan Laut dan Kepelabuhanan serta Prosedur Impor Barang [Operational Management of Sea Transportation, Port, and Import Procedure]. Jakarta: PT. Gramedia Pustaka Utama.
Timor, H. Z., 2014. Analisis Kinerja Terminal Multipurpose Nilam Timur Tanjung Perak dari Aspek Produksi Peti Kemas [Performance Analysis of East Nilam in Tanjuk Perak Port from Container Products Aspect], Yogyakarta: Universitas Gadjah Mada.

Triatmodjo, B., 2003. Port. Yogyakarta: Beta Offset.

Triatmodjo, B., 2010. Port Design. Yogyakarta: Beta Offset.

Yuwono, N., 2009. Transportasi Air [Water Transportation], Yogyakarta: Magister of System and Transportation Engineering, Department of Civil and Environmental Engineering UGM. 
[this page intentionally left blank] 